\title{
A Diterpenoid Taxoquinone from Metasequoia glyptostroboides with Pharmacological Potential
}

\author{
Vivek Kumar Bajpai ${ }^{1}$, Irfan Ahmad Rather ${ }^{1}$, Sun Chul Kang ${ }^{2, *}$, Yong-Ha Park ${ }^{1, *}$ \\ 'Department of Applied Microbiology and Biotechnology, School of Biotechnology, Yeungnam University, Gyeongsan, \\ Gyeongbook 712-749, KOREA. \\ ${ }^{2}$ Department of Biotechnology, College of Engineering, Daegu University, Gyeongsan, Gyeongbook 712-714, KOREA.
}

\begin{abstract}
Background: The ubiquitin-proteasome pathway plays an important role in selective protein degradation and regulates multiple cellular processes, including cell cycle progression, proliferation and apoptosis. Cancer cells are more sensitive to the pro-apoptotic effects of proteasome inhibition than normal cells, hence, proteasome inhibitors can be used as novel anticancer drugs. Further, influenzacommonly known as "flu" is a contagious respiratory disease caused by sub-type of influenza A virus $\mathrm{H} 1 \mathrm{~N} 1$ which has resulted in enormous medical attention world-wide. Natural products are well known for their pharmacological potential in anticancer and antiviral therapies. Methods: In this study, an abietane-type diterpenoid, taxoquinone, isolated from Metasequoia glyptostroboides, was assessed for the first time for its therapeutic efficacy as a potential inhibitor of influenza A (H1N1) virus and 20S proteasomeusing cytopathic reduction assay and proteasome inhibition assay, respectively. Results: The taxoquinonedisplayed its anticancer effect in terms its ability to inhibit $20 \mathrm{~S}$ human proteasome with $\mathrm{IC}_{50}$ value of $8.2 \pm 2.4 \mu \mathrm{g} / \mu \mathrm{L}$. Moreover, taxoquinone $(500 \mu \mathrm{g} / \mathrm{mL})$ displayed significant antiviral effect against $\mathrm{H} 1 \mathrm{~N} 1$ influenza virus in cytopathic reduction assay on MDCK cell line. Conclusion: These finding confirm pharmaceutical potential of taxoquinone as a novel therapeutic agent.
\end{abstract}

Key words: Anticancer, Antiviral, Taxoquinone, Diterpenoid, Metasequoia glyptostroboides.

\section{INTRODUCTION}

The ubiquitin-proteasome pathway (UPP) abundantly demonstrates that the proteasome is the pivotal component in cancer therapy. The UPP participates in the regulation of numerous cellular and physiological functions through specific targeted destruction of regulatory proteins. ${ }^{1}$ Proteasomes are large multimeric protease complexes, presenting multiple targets for therapeutic intervention, that selectively and timely degrade most cellular proteins. ${ }^{2}$ The ubiquitination of target proteins is an important mechanism for the discriminatory nature of protein degradation by proteasomes. Protein degradation by the proteasome is regulated by the ubiquitin system. The ubiquitin is a highly, evolutionarily conserved, 76-amino acid protein that serves as a tag for destruction of targeted proteins through covalent binding. On the attachment of polyubiquitin to target proteins, tagged proteins are selected for destruction by cytoplasmic organelles called proteasomes. ${ }^{2}$ The potential of specific proteasome inhibitors to function as anticancer agents is now of considerable interest, and has opened a new field in the cancer drug discovery. ${ }^{3}$ It has been shown that human cancer cells are more sensitive to proteasome inhibition than normal cells, indicating that a proteasome inhibitor could be used as a novel anticancer drug. In fact, this idea has been supported by the encouraging results of the clinical trials using the proteasome inhibitors.

It has been reported that some of the currently available proteasome inhibitors have
Submission Date : 28-11-2015 Revision Date : 29-02-2016 Accepted Date : :05-03-2016

DOI: 10.5530/ijper.50.3.20 Correspondence: Prof. (Dr.) Sun Chul Kang* Prof. (Dr.) Yong-Ha Park* Prof. (Dr.)Vivek K. Bajpai* E-mail: vbajpai04@yahoo. com; Fax: +82-53-813-4620

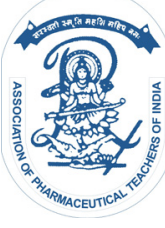

www.ijper.org 
undesirable side effects such as fatigue, nausea, vomiting, peripheral neuropathy, anemia, diarrhea, and constipationalong with their toxicity issues, thus cannot be used in vivo. ${ }^{1}$ Therefore, there has been a growing interest for generating broad-spectrum proteasome inhibitors of natural origin, especially from natural products for the preventive treatment of a variety of cancers to overcome chemotherapeutic side effects. ${ }^{1,4}$

Influenza A (H1N1) is the sub-type of influenza A virusthat is known as the most common cause of human influenza. Influenza, commonly known as 'flu' is a contagious respiratory disease induced by influenza viruses. It has been confirmed that over 220,000 hospitalizations and approximately 36,000 annual deaths are reported by influenza viruses in the United States every year. ${ }^{5,6}$ Current scenario on emergence of life threatening viruses has resulted in enormous attention on finding new effective class of antiviral drugs of natural origin due to the restricted efficacy of currently available vaccination program, ${ }^{6,7}$ and limited use of chemical synthesized antiviral drugs against influenza viruses. ${ }^{8}$ This has created an alarming demand for the development of unconventional form of measure against influenza virus. Metasequoia glyptostroboides is a deciduous coniferous tree which has been found to propagatein Eastern Asia, North America, and Europe. M. glyptostroboides has not been studied to a great extent, hence, in our ongoing efforts to find out biologically active compounds from natural products, in this study, a diterpenoid compound, taxoquinone, previously isolated from $M$. glyptostroboides was assessed for the first time for it anticancer and antiviral potential in terms of its ability to inhibit $20 \mathrm{~S}$ proteasome activity and in vitro propagation of influenza virus H1N1, respectively. Previously we reported antibacterial and antioxidant potential of Metasequoia glyptostroboides derived secondary metabolites including taxoquinone. ${ }^{9-11}$

To the best of our knowledge, no research has been reported on the proteasome inhibitory activity and antiviral potential of taxoquinone. Hence, in this study, we evaluated anticancer (human proteasome inhibition) and antiviral (influenza virus $\mathrm{H} 1 \mathrm{~N} 1$ inhibition) properties of an abietane-type diterpenoid taxoquinone.

\section{MATERIALS AND METHODS}

\section{Chemicals and Instrument}

A commercially available 20S Proteasome Assay Kit for Drug Discovery-BML-AK740 (Enzo Life Sciences, Postfach, Switzerland) was used, which provided the purified, human erythrocyte $20 \mathrm{~S}$ proteasome, assay buffer, and fluorogenic peptide substrate Suc-LLVY-AMC. Proteasome inhibition was determined using a fluorescent 96-well micro-plate ELISA reader (Infinite M200, Tecan, Mannedorf, Switzerland) which measures the fluorescence of free AMC from Suc-LLVY-AMC.

\section{Plant Materials}

The cones of $M$. glyptostroboides were collected from Pohang city, Korea, in November and December 2008, and identified by the morphological features and the database present in the library at the Department of Biotechnology, Daegu University, Korea. A voucher specimen was deposited in the herbarium of Department of Biotechnology, Daegu University, Korea. ${ }^{10}$

\section{Extraction, Isolation and Purification of Taxoquinone}

Dried cones of $M$. glyptostroboides $(2 \mathrm{~kg}$ ) were milled into powdered form and then extracted with ethyl acetate at room temperature for 12 days. The extract was evaporated under reduced pressure using a rotary evaporator (EYELA N1000, Japan). The dried ethyl acetate extract (7 g) was subjected to column chromatography over silica gel (mesh 230-400 mesh, Merck, Darmstadt, Germany) and was eluted with hexane-ethyl acetatemethanol solvent system to give 20 fractions. Of the fractions obtained, fraction-12 was further purified by preparative TLC over silica gel $\mathrm{GF}_{254}$ using hexane-ethyl acetate (1:2) as a mobile phase to give one compound $(152 \mathrm{mg})$ which on the basis of spectral data analysis was characterized as taxoquinone. ${ }^{10}$

\section{Anticancer Potential of Taxoquinone (20S Proteasome Inhibition Assay)}

The proteasome inhibition assay was done as follows; $3 \%$ sodium dodecyl sulfate was added to assay buffer to activate the $20 \mathrm{~S}$ proteasome's chymotrypsin-like activity. ${ }^{4}$ The assay buffer was added to the blank and sample plate, and a diluted solution of positive control was added to the inhibitor wells. The enriched proteasome fraction was diluted to a final assay concentration of $10 \mu \mathrm{g} / \mathrm{mL}$ using assay buffer. This diluted fraction was then added to each well, and then, the plate was pre-incubated for $10 \mathrm{~min}$ at $37^{\circ} \mathrm{C}$ to allow the inhibitor and enzyme to interact. The enzymatic reaction was started by adding Suc-LLVY-AMC substrate to a final concentration of $75 \mu \mathrm{M}$. The chymotrypsin-like enzymatic activity of the proteasome was determined by measuring the generation of free AMC using a fluorescent ELISA plate reader, capable of excitation at a wavelength of $360 \mathrm{~nm}$ and detection of emitted light at $460 \mathrm{~nm}$. Epoxomicin was used as the positive control, 
which is a rapid, potent and irreversible inhibitor of the $20 \mathrm{~S}$ proteasome chymotrypsin-like activity.

\section{Culture of MDCK Cell Line}

Madin-Darby canine kidney (MDCK) cells (KTCC $®$ AC30015) used in this study were grown in high-glucose Dulbecco'smodified Eagle's medium (DMEM) (SigmaAldrich, St. Louis, MO) supplemented with 10\% heat-inactivated standard fetal bovine serum (FBS) (HyClone, Logan, UT) and 1\% (v/v) $100 \mathrm{U} / \mathrm{mol}$ penicillin and $100 \mu \mathrm{g} / \mathrm{mL}$ streptomycin solution at room temperature $\left(23 \pm 1^{\circ} \mathrm{C}\right)$ undernormal atmospheric conditions. Cells were sub-cultured at a 1:3 ratio every 3-4 days. Briefly, DMEM medium from TC-75 $\mathrm{cm}^{2}$ flasks was collected and centrifuged at 1,500 rpm for $5 \mathrm{~min}$. Meanwhile, $5 \mathrm{~mL} /$ flask of a trypsin-versine solution (10 mL 10x Trypsin(Sigma-Aldrich, St. Louis, MO) in $90 \mathrm{~mL}$ pre-sterilizedversine (EDTA) solution was added and incubated for $1 \mathrm{~min}$ to detach thecell monolayer. ${ }^{12}$ Following cell detachment, cleaned medium was added back into the flasks to neutralize thetrypsin activity. The contents of the flasks were then removed and centrifuged at 1,500 rpm for $5 \mathrm{~min}$. Following centrifugation, supernatant was removed and new growth medium was used to re-suspend the cells. Cells, split 1:3, were placed back into flasks and to talmedia volume was brought up to $20-22 \mathrm{~mL} /$ flask. Flasks were then placed back into their respective incubators and monitored daily.

\section{Virus Culture and Harvesting of H1N1 Virus from Embryonated Egg}

Highly pathogenic influenza virus (IFV) H1N1 (A/Korea/ 01/2009) was obtained from Korea Centers for Disease Control and Prevention, Korea. The IFV H1N1 was grown in the allantoic cavity of 11 days old chicken embryo for 3 days. In brief, specificpathogen-free (SPF) chicken eggs were cleaned by $70 \%(\mathrm{v} / \mathrm{v})$ ethanol and incubated for embrocation in a rotating and static egg incubator for at $35^{\circ} \mathrm{C}$ with humidified environment for 11 days. After that, $100 \mu \mathrm{L}$ of IFV H1N1 was inoculated in the allantoic cavity by using $1 \mathrm{~mL}$ syringe with 27-gauge, 1-inch or 1.5-inch hypodermic or blunt-end needle and the punched holes were sealed with wax followed by incubation at $35^{\circ} \mathrm{C}$ in a humidified static incubator for 2-3 days. At the completion of incubation period, eggs were prepared for fluid collection by placing them on ice $\left(\right.$ at $\left.4^{\circ} \mathrm{C}\right)$ overnight. Then, $3 \mathrm{~mL}$ syringe with a 21-gauge, 1-inch hypodermic needle was used to collect the harvested allantoic fluid. Allantoic fluid was stored at $-80^{\circ} \mathrm{C}$ as a stock solution of the IFV H1N1 A virus. Virus titers in the allantoic fluid stock solution were determined as anembryo infectiondose
$10^{5.5} \mathrm{EID}_{50} / 0.1 \mathrm{~mL}$ using $50 \%$ end point dilution assay as described by Reed and Muench. ${ }^{13}$

\section{Antiviral Potential of Taxoquinone (CytopathicReduction Assay)}

For assessing the cytopathic reduction effect of the taxoquinone, MDCK cell line was cultured in a 96 well microplate using Eagle's minimal medium (MEM) with $10 \%(\mathrm{v} / \mathrm{v})$ fetal bovine serum (FBS), $1 \%(\mathrm{v} / \mathrm{v}) 100 \mathrm{U} / \mathrm{mol}$ penicillin and $100 \mu \mathrm{g} / \mathrm{mL}$ streptomycin solution for $24-36 \mathrm{~h}$ at $37^{\circ} \mathrm{C}$, with $5 \% \mathrm{CO}_{2}$ in a cell-culture incubator. MDCK cells were seededonto a 96-well culture plate at the concentration of $2 \times 10^{4}$ cells per well. Sugiol was serially diluted two-fold with $2 \%$ FBS DMEM solution. IFV $\mathrm{H}_{1} \mathrm{~N}_{1}$ was treated with two-fold diluted samples of taxoquinone at $37^{\circ} \mathrm{C}$, and $5 \% \mathrm{CO}_{2}$ in cell culture incubator for $1 \mathrm{~h}$. This mixture was inoculated into MDCK cells and incubated in DMEM solution with 2\% FBS at $37^{\circ} \mathrm{C}$ in a humidified chamber with $5 \% \mathrm{CO}_{2}$ for $72 \mathrm{~h}$ using a multi-pipette. The plates were observed for cytopathic effect (CPE) after $72 \mathrm{~h}$, and the reduction of CPE was regarded as the presence of antiviral activity. ${ }^{6,14}$

\section{Statistical Analysis}

The data were expressed as the mean $\pm \mathrm{SD}$ of three independent experiments and analyzed using one-way analysis of variance and Student's t-test. $\mathrm{p}$ values of $<0.05$ were considered to be statistically significant.

\section{RESULTS AND DISCUSSION}

\section{Taxoquinone}

The ethyl acetate cone extract of M. glyptostroboides after column chromatography over silica gel yielded a pure compound which was obtained as orange needles with a specific melting point $\left(\mathrm{mp} 212-214^{\circ} \mathrm{C}\right)$. The ${ }^{1} \mathrm{H}$ NMR spectrum $\left(\mathrm{CDCl}_{3}, 250 \mathrm{MHz}\right)$ of the compound showed a hydroxyl methine signal at d $4.77(1 \mathrm{H}$, ddd, $J=2.2$, $7.4,9.8 \mathrm{~Hz})$, an oxygenated proton at d $3.80(1 \mathrm{H}, \mathrm{d}$, $J=2.2 \mathrm{~Hz})$, an aliphatic methine at d $3.14(1 \mathrm{H}$, sept, $J=7.1 \mathrm{~Hz}$ ), and proton signals for methylene (d 2.65-1.01) and five terminal methyl groups (d 1.33, 1.20, 1.19, 0.92, and 0.90). Further analysis of the COSY data established the connectivity through $\mathrm{H}-7 \mathrm{a}$ (d 4.77, ddd, $J=2.2,7.4$, $9.8 \mathrm{~Hz}), 7 \mathrm{~b}-\mathrm{OH}(\mathrm{d} 3.80, \mathrm{~d}, J=2.2 \mathrm{~Hz})$, and $\mathrm{H}-6 \mathrm{~b}$ (d 2.18, dd, $J=7.4,12.5 \mathrm{~Hz}$ ), and through $\mathrm{H}-1 \mathrm{~b}$ (d 2.65, br d, $J=13.0 \mathrm{~Hz}), \mathrm{H}-2 \mathrm{~b}(\mathrm{~d} 1.71, \mathrm{~m})$, and H-1a, 2a, 3a, 3b (1.65-1.01, m). In addition, two methyl signals at $\mathrm{d} 1.20(3 \mathrm{H}, \mathrm{d}, J=7.1 \mathrm{~Hz})$ and $1.19(3 \mathrm{H}, \mathrm{d}, J=7.1 \mathrm{~Hz})$ coupling with a methine signal at d $3.14(1 \mathrm{H}$, sept, $J=7.1 \mathrm{~Hz}, \mathrm{H}-15)$ in the ${ }^{1} \mathrm{H}$ NMR data as well as 20 carbon signals including two carbonyl groups at $\mathrm{d} 189.6$ 
and 183.7 in the ${ }^{13} \mathrm{C}$ NMR data strongly suggested that this compound should be an abietane diterpenoid. On the basis of the interpretation of HMQC and HMBC data, this compound was proposed to be taxoquinone. ${ }^{15}$ By comparison of the multiplicity of $\mathrm{H}-7$ and the chemical shifts both in the ${ }^{1} \mathrm{H}$ and ${ }^{13} \mathrm{C}$ NMR data, the structure of this compound (Figure 1) was determined to be taxoquinone. . $^{10,15,16}$

\section{Inhibition of 20S Human Proteasome}

Nowadays attention has been focused on finding natural inhibitors of proteasome due to their potent anticancer potential. ${ }^{1,17}$ Particularly, bortezomib, NPI-0052, and lactacystin, have been considered specific protease inhibitors for the treatment of variety of cancers, due to their direct growth-inhibitory and apoptotic effects on cancer cells as also approved by USFDA. In addition, several evidences from pre-clinical and clinical trials have supported the hypothesis that targeting the proteasome inhibition could be a promising strategy for the treatment of variety of cancers. Since the discovery of first generation of proteasome inhibitors, including bortezomib and lactacystin, a largerange of otherchemically synthesized proteasome inhibitors were developed and isolated from natural resources for the treatment of multiple myeloma cancer cells. ${ }^{1}$ Previously relationship between proteasomal chymotrypsin-like activity and tumor growth demonstrated potent efficacy of withaferin A (steroidal lactone), an effective inhibitor of angiogenesis, resulting in tumor growth inhibition associated with inhibition of tumor tissue proteasomal chymotrypsin-like activity. ${ }^{1}$

To investigate the $20 \mathrm{~S}$ proteasome inhibitory activity of taxoquinone, commercially available purified human erythrocyte $20 \mathrm{~S}$ proteasome was used in this study. Suc-Leu-Leu-Val-Tyr linked to fluorogenic aminomethylcou marin (Suc-LLVY-AMC) was used as a substrate to determine the chymotrypsin-like activity of $20 \mathrm{~S}$ proteasome. The inhibitory activity was determined by measuring the generation of free AMC using a fluorescence plate reader after adding Suc-LLVY-AMC to the incubated mixtureof compoundand $20 \mathrm{~S}$ proteasome. The inhibitory activity of taxoquinone against $20 \mathrm{~S}$ proteasome has been presented in Figure 2. Interestingly, taxoquinone inhibited the activity of $20 \mathrm{~S}$ proteasome in a dose-dependent manner with $\mathrm{IC}_{50}$ values of $8.2 \pm$ $2.4 \mu \mathrm{g} / \mu \mathrm{L}$. A known proteasome inhibitor, epoxomicin $\left(\mathrm{IC}_{50} 5.1 \pm 1.4 \mu \mathrm{g} / \mu \mathrm{L}\right)$, was employed as a positive control in this assay.

Various proteins involved in the processes of carcinogenesis and cancer survival have been identified as targets of the proteasome, including cyclins A, B, D and E, as well as tumor suppressor protein p53, pro-apoptotic protein $\mathrm{Bax}$, cyclin-dependent kinase inhibitor (CKI) p27, and the inhibitor of NF- $x \mathrm{~B}$, and $\mathrm{I} x \mathrm{~B}-\alpha .{ }^{1}$ Specific inhibition of chymotrypsin-like activity is an efficient biological effect for the induction of neurite outgrowth, and apoptosis in cancer cells. To reduce the recovery period and potentially promote the efficacy of chemotherapeutics, it is critical to eliminate noxious substances in the treatment of cancer. Hence, cancer-preventive and anticancer effects of natural products are widely supported by the results obtained from epidemiological, cell culture, and animal studies, and a number of microbial metabolites and plant polyphenols have been implicated as natural proteasome inhibitors. ${ }^{1}$

The ubiquitin-proteasome proteolytic system plays an important role in selective protein degradation and regulates cellular events, including cell-cycle progression, apoptosis, and inflammation. ${ }^{18}$ Since proteasomes interact primarily with endogenous proteins, inhibition of the proteasome may block the signaling action of the transcription factor NF- $x \mathrm{~B}$, thus inhibit the completion of the cell cycle and the mitotic proliferation of cancerous cells, leading to cell death by apoptosis, and inhibition of angiogenesis and metastasis. Previously $20 \mathrm{~S}$ proteasome inhibitory activities of various natural products including, coumarins, terpenes, flavonoids, phenols and saponins have been reported by others. ${ }^{4,17,19}$ In addition, biological structure activity relationship also gives conformational evidences that presence of carbonyl group in taxoquinonemay influence the inhibitory activity against $20 \mathrm{~S}$ proteasome. ${ }^{20}$ It has been reported that carbonyl carbon in natural compounds is electrophilic. Electrophilic functional groups of inhibitors are susceptible to be attacked by the proteolytically active $T h r 1 \mathrm{O}^{\gamma}$ that is nucleophilic, which might be responsible for the observed inhibitory effect of taxoquinone on $20 \mathrm{~S}$ proteasome. $^{20}$

Moreover, a number of diterpenoid compounds exhibit anticancer and antitumor effects or induce apoptosis, associated with cell cycle arrest at the $G(2) / M$ phase, modulation of cyclin expression and by downregulating the proto-oncogene c-myc, as well asinhibit bcl-x $(\mathrm{L})$ expression, which together cause DNA fragmentation and nuclear chromatin condensation. It has been reported that a diterpenoid induces apoptosis in human leukemia cells through a caspase-8-dependent pathway. ${ }^{21}$ Treatment of human leukemia cancer cells by kaurene type diterpenoid led to a time-dependent cleavage of Bid, a substrate of caspsase- 8 , as well as to the proteolytic processing of procaspase- 8 , indicating that kaurene type diterpenoid compounds induce apoptosis through caspase-8-dependent pathway. ${ }^{21}$ In addition, over 


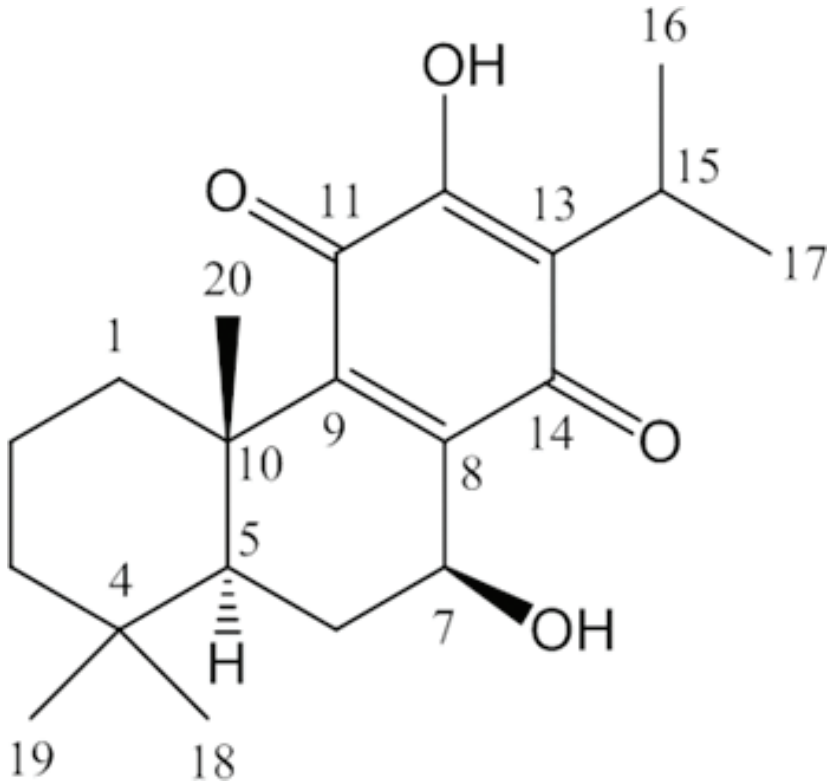

Figure 1: Chemical structure of taxoquinone, an abietane-type diterpenoid isolated from M. glyptostroboides.

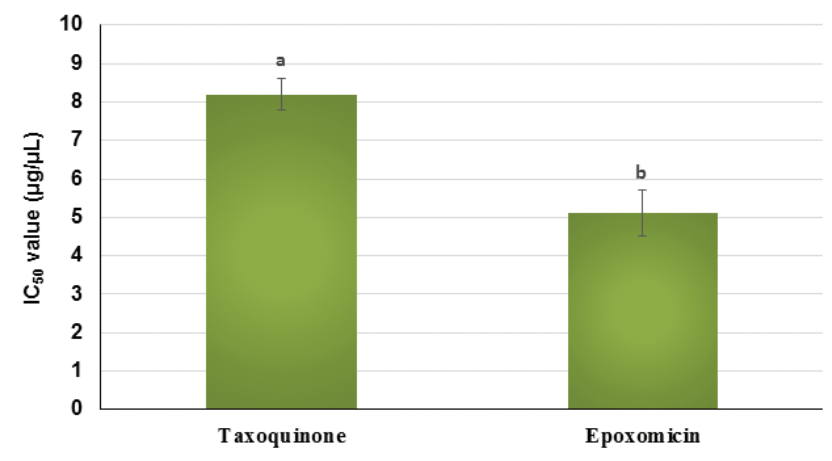

Figure 2: Anticancer effect of an abietane-type diterpenoid taxoquinone on the inhibition of $20 \mathrm{~S}$ human proteasome.

expression of drug resistance factor $\mathrm{Bcl}-2$, which is frequently over expressed in many tumors, failed to confer resistant to diterpenoid-induced cytotoxicity. ${ }^{21}$ Similarly, other researchers have also reported antitumor and/or anticancer efficacy of various terpenoid compounds in various cancer cell lines. ${ }^{1,22}$ Based on these findings, it is speculated that specific inhibition of chymotrypsin-like activity is an efficient biological effect for the induction of neurite outgrowth, and apoptosis in cancer cells, ${ }^{1}$ suggesting a positive correlation of taxoquinone as an effective anticancer molecule on proteasome inhibition.

\section{Inhibition of H1N1 Influenza Virus}

Nowadays human population has been markedly affected by the highly contagious influenza viruses world-wide. In general, severity of influenza virus infection has been commonly observed in the mucous membranes

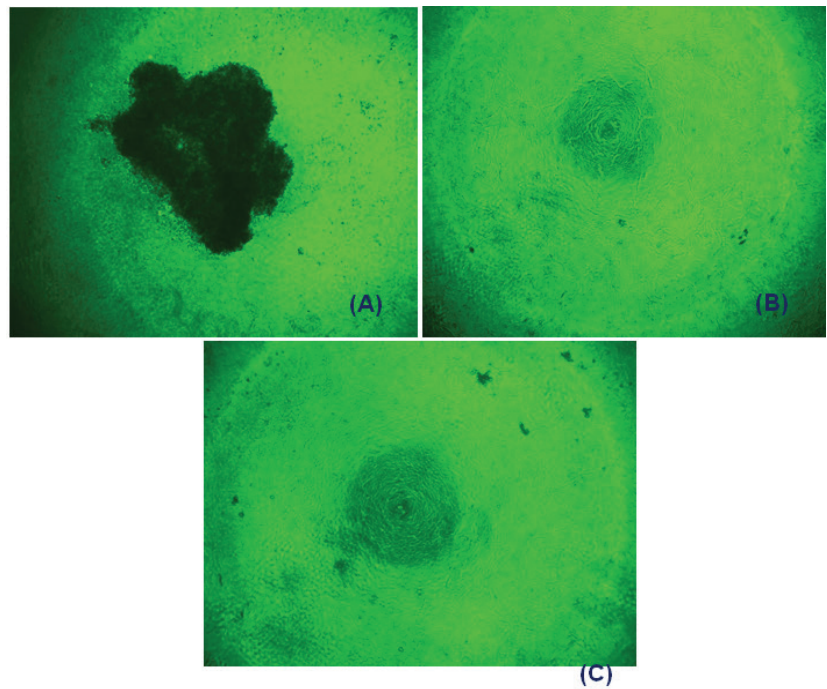

Figure 3: Antiviral potential of an abietane-type diterpenoid taxoquinone against H1N1 virus in MDCK cells. Visualization ofcytopathogenic effect through the condensation of MDCK cells treated with $\mathrm{H} 1 \mathrm{~N} 1$ virus $(\mathrm{A})$; control - normal MDCK cells without any treatment (B); and MDCK cells treated with taxoquinoneand H1N1 (C). Pictures were taken under fluorescence microscope at a magnification of $40 x$.

of the upper respiratory tract, however, it may also cause deleterious effect on human lungs, ${ }^{23}$ leading to secondary infection in susceptible individuals such as infants and the elderly. ${ }^{24}$ Influenza viruses are classified into type $\mathrm{A}, \mathrm{B}$ and $\mathrm{C}$, with type $\mathrm{A}$ appearing to be the most notorious candidate. ${ }^{25}$ The epidemiology of influenza virus type $\mathrm{A}$ and $\mathrm{B}$ is distinctive due to their seasonality and antigenic variation. The gradual antigenic drift of influenza virus type A and B coupled with occasional antigenic shift make it difficult to control the infection. ${ }^{25}$ Current therapeutic agents against influenza viruses include amantadine and rimantadine, however, severe side effects and development of resistance have limited their practical applications, generating a huge need to develop new, effective and broad-spectrum antiviral agents.

To confirm the biomedicinal potential, taxoquinone was assessed for it santiviral efficacy against influenza virus $\mathrm{H} 1 \mathrm{~N} 1$ on MDCK cells. It was observed that H1N1 induced cytopathic effect (CPE) in MDCK cells when used alone (Figure 3A). However, no CPE was observed in control MDCK cells (Figure 3B). Microscopic observations confirmed that MDCK cells treated with $\mathrm{H} 1 \mathrm{~N} 1$ and taxoquinone showed similar morphology as did by the control MDCK cells (without any treatment) even after $72 \mathrm{~h}$ of the viral injection (Figure 3C). These results confirmed that taxoquinone isolated from $M$. glyptostroboides could be a potent antiviral candidate able to control CPE in MDCK cells caused by influenza 
virus H1N1. Natural products such as terpenes or terpenoidshave shown great potential of therapeutic efficacy in terms of their potent antiviral efficacy against various types of viruses. As reported previously, sterols and terpenoids such as ganoderone A, lucialdehyde B, and ergosta-7,22-dien-3â-ol also exhibited profound antiviral effect against herpes simplex virus. ${ }^{26} \mathrm{~A}$ sesquiter penoid, gossypol isolated from the cotton seeds has been found to exhibit antiviral activity and inhibited the growth of influenza virus in vitro. ${ }^{27}$ In addition, glycyrrhizin, a terpenoid isolated from higher plantsexhibited significant antiviral activity against influenza virus in vitro. ${ }^{28}$

Antiviral efficacy of polyphenolic compounds has also been reviewedpreviously, ${ }^{29}$ and it was found that compounds of terpene nature have potential efficacy to inhibit in vitro growth of influenza virus H1N1. From these findings, it can beestimated that antiviral activity of polyphenolic compounds might be associated with the inhibition of hemagglutination activity(HA), because HAs of different sub-types usually express distinct antigenic signature in the globular head domain ${ }^{29}$ suggesting this activity might be occurred by the non-specific masking of HA heads. These findings demonstrated that taxoquinone, being a terpene family member, may also inhibit in vitro growth of H1N1 influenza virus via similar mechanism. In addition, inhibition of viral protein maturation via blocking of signaling pathways may also be proposed as an antiviral action of taxoquinone as also observed previously. ${ }^{29}$

\section{CONCLUSION}

Therapeutic efficacy of terpenoid compounds as natural inhibitors of human proteasome and influenza virus may provide a viable modality on the crucial role of proteasome in the pathological state of cancer and contagious respiratory H1N1 influenza virus for the preventive treatment of cancer and viral disorders. This could be considered the first report on the inhibitory effect of taxoquinone on $20 \mathrm{~S}$ human proteasome and influenza virus $\mathrm{H} 1 \mathrm{~N} 1$, and the results of the study indicate that taxoquinone could be a promising anticancer and antiviral agent, as confirmed by its chymotrypsin-likeinhibitory activity on human $20 \mathrm{~S}$ proteasome and in vitro growth inhibition of influenza virus H1N1 on MDCK cell line. This study reinforces the suggestions that using an innocuous natural productsas monotherapy or in synergismmay boost the effectiveness of current chemotherapeutics, leading to the development of a new and safer classes of potential anticancer and antiviral drugs.

\section{ACKNOWLEDGEMENT}

None.

\section{CONFLICT OF INTEREST}

None of the authors has a conflict of interest to disclose.

\section{ABBREVIATION USED}

MDCK: Madin-Darby canine kidney; ELISA: Enzyme linked immunosorbent assay; DMEM: Dulbecco's modified Eagle's medium; FBS: Fetal bovine serum; MEM: Minimal Eagle's medium; IFV: Influenza virus; NMR: Nuclear magnetic resonance; USFDA: United State Food Drug Administration; CPE: Cytopathic effect.

\section{REFERENCES}

1. Yang $H$, Landis-Piwowar KR, Chen D, Milacic V, Dou QP. Natural compounds with proteasome inhibitory activity for cancer prevention and treatment. Curr Protein Pept Sci. 2008;9(3):227-39. http://dx.doi. org/10.2174/138920308784533998; PMid:18537678:PMCid:PMC3303152.

2. Bogyo M, Wang EW. Proteasome inhibitors: complex tools for a complex enzyme. Curr Top Microbiol Immunol. 2002;268:185-208. http://dx.doi. org/10.1007/978-3-642-59414-4_8.

3. Chen D, Landis-Piwowar KR, Chen MS, Dou QP. Inhibition of proteasome activity by the dietary flavonoid apigenin is associated with growth inhibition in cultured breast cancer cells and xenografts. Breast Can Res. 2007;9:1-8. http://dx.doi.org/10.1186/bcr1632; PMid:17201918:PMCid:PMC1851382.

4. Shim SH. 20S Proteasome Inhibitory Activity of Flavonoids isolated from Spatholobus suberectus. Phytother Res. 2010;25:615-8. http://dx.doi. org/10.1002/ptr.3342; PMid:21104764.

5. Thompson WW, Shay DK, Weintraub E, Brammer L, Bridges CB, Cox NJ, et al. Influenza-associated hospitalizations in the United States. JAMA. 2004;292:1333-40. http://dx.doi.org/10.1001/jama.292.11.1333; PMid:15367555.

6. Rather IA, Choi KH, Bajpai VK, Park YH. Antiviral mode of action of Lactobacillus plantarum YML009 on influenza virus. Bang $\mathrm{J}$ Pharmacol. 2014;9:475-82.

7. Hancock K, Veguilla V, Lu X, Zhong W, Butler EN. Cross -reactive antibody responses to the 2009 pandemic H1N1 influenza virus. New Eng J Med. 2009;361:1945-52. http://dx.doi.org/10.1056/NEJMoa0906453; PMid:19745214.

8. Beigel J, Bray M. Current and future antiviral therapy of severe seasonal and avian influenza. Antiviral Res. 2008;78:91-102. http://dx.doi.org/10.1016/j. antiviral.2008.01.003; PMid:18328578:PMC2346583.

9. Bajpai VK, Kang SC. Isolation and characterization of biologically active secondary metabolites from Metasequoia glyptostroboides Miki Ex Hu. J Food Safety. 2011;31:276-83. http://dx.doi.org/10.1111/j.1745-4565.2011.00298.x

10. Bajpai VK, Na MK, Kang SC. The role of bioactive substances in controlling foodborne pathogens derived from Metasequoia glyptostroboides Miki ex Hu. Food Chem Toxicol. 2010;48:1945-49. http://dx.doi.org/10.1016/j. fct.2010.04.041; PMid:20435080.

11. Bajpai VK, Sharma, A, Kang SC, Baek KH. Antioxidant, lipid peroxidation and free radical scavenging efficacy of a diterpenoid compound sugiol isolated from Metasequoia glyptostroboides. Asian Pac J Trop Med. 2014;7:9-15. http://dx.doi.org/10.1016/S1995-7645(13)60183-2.

12. Lu Y, Aguirre AA, Hamm C, Wang Y, Yu Q, Loh PC, Yanagihara R. Establishment, cryopreservation, and growth of 11 cell lines preparedfrom 
a juvenile Hawaiian monk seal, Monachus schauinslandi. Meth Cell Sci. 2000;22:115-24. http://dx.doi.org/10.1023/A:1009816715383.

13. Reed LJ, Muench H. A simple method of estimating fifty percent endpoints. Am J Hyg. 1938;27:493-7.

14. Seo BJ, Rather IA, Kumar VJ, Choi UH, Moon MR, Lim JH, et al. Evaluation of Leuconostoc mesenteroides YML003 as a probiotic against low-pathogenic avian influenza (H9N2) virus in chickens. J Appl Microbiol. 2012;112:163-71. http://dx.doi.org/10.1111/j.1365-2672.2012.05326.x; PMid:22548634.

15. Kupchan SM, Karim A, Marcks C. Taxodione and taxodone, two novel diterpenoid quinone methide tumor inhibitors from Taxodium distichum. J Am Chem Soc. 1969;90:5923-24. http://dx.doi.org/10.1021/ja01023a061.

16. Rodríguez B. $1 \mathrm{H}$ and $13 \mathrm{C}$ NMR spectral assignments of some natural abietane diterpenoids. Mag Reson Chem. 2003;41:741-6. http://dx.doi. org/10.1002/mrc.1245.

17. Kim YJ, Lee H, Park EH, Shim SH. Inhibition of human 20 S proteasome by compounds from seeds of Psoralea corylifolia. Bull Korean Chem Soc. 2009;30:1867-9. http://dx.doi.org/10.5012/bkcs.2009.30.8.1867.

18. Lecker SH, Goldberg AL, Mitch WE. Protein degradation by the ubiquitin-proteasome pathway in normal and disease States. J Am Soc Nephrol. 2006;17:1807-19. http://dx.doi.org/10.1681/ASN.2006010083; PMid:16738015

19. Shim SH, Baek KH, Kim YS. Inhibition of human $20 \mathrm{~S}$ proteasome by ginsenosides from Panax ginseng. Bull Korean Chem Soc. 2009;30:1385-7. http://dx.doi.org/10.5012/bkcs.2009.30.6.1385.

20. Groll M, Huber R. Inhibitors of the eukaryotic 20S proteasome core particle: a structural approach. Biochim Biophys Acta. 2004;1695:33-44. http://dx.doi. org/10.1016/j.bbamcr.2004.09.025; PMid:15571807.
21. Kondoh M, Suzuki I, Sato M, Nagashima F, Simizu S, Harada M, et al. Kaurene diterpene induces apoptosis in human leukemia cells partly through a capase-8-dependent pathway. J Pharmacol Exp Ther. 2004;311:115-22. http://dx.doi.org/10.1124/jpet.104.069690; PMid:15161936.

22. Chen G, Wang F, Trachootham D, Huang P. Preferential killing of cancer cells with mitochondrial dysfunction by natural compounds. Mitochondrion. 2010;10:614-25. http://dx.doi.org/10.1016/j.mito.2010.08.001; PMid:20713185:PMC3085019.

23. Brock TD, Madigan MT, Marrtinko JM, Parker I. Biology of Microorganisms: Influenza virus 7th Edn. Prentice-Hall: Upper Saddle River, NJ 1997.

24. Kent IH, Chapman LE, Schmelts LM, Regnery HL, Cox NJ, Schonberger LB. Influenza surveillance-United States. Morb Mortal Wkly Rep. 1992;41:35-46.

25. Park KJ. Evaluation of in vitro antiviral activity in methanol extracts against influenza virus type A from Korean medicinal plants. Phytother Res. 2003;17:1059-63. http://dx.doi.org/10.1002/ptr.1330; PMid:14595587.

26. Niedermeyer THJ, Lindequist U, Mentel R, Gordes D, Schmidt E, Thurow K, et al. Antiviral terpenoid constituents of Ganoderma pfeifferi. J Nat Prod. 2005;68:1728-31. http://dx.doi.org/10.1021/np0501886 ; PMid:16378363.

27. Polsky B, Segal SJ, Baron PA, Gold JW, Ueno H, Armstrong D. Inactivation of human immunodeficiency virus in vitro by gossypol. Contraception. 1989;39:579-87. http://dx.doi.org/10.1016/0010-7824(89)90034-6.

28. Vanden Berghe DAR, Haemers A, Vlietinck AJ. Antiviral agents from higher plants and an example of structure-activity relationship of 3-methoxyflavones. In: Ed. Steven M. Colegate. Bioactive Natural Products: detection, isolation and structural determination, New York, CRC Press. 1993;pp.405-440.

29. Park S, Kim JI, Lee I, Lee S, Hwang MW, Bae JY, et al. Aronia melanocarpa and its components demonstrate antiviral activity against influenza viruses. Biochem Biophys Res Comm. 2013;440:14-9. http://dx.doi.org/10.1016/j. bbrc.2013.08.090; PMid:24012672.

\section{SUMMARY}

- This study reports pharmacological efficacy of a diterpenoid compound, taxoquinone isolated from Metasequoia glyptostroboides.

- Taxoquinone exhibited significant anticancer effect in terms its ability to inhibit $20 \mathrm{~S}$ human proteasome.

- Taxoquinone exhibited significantantiviral effect against H1N1 influenza virus in cytopathic reduction assay on MDCK cell line.

- The diterpenoid compound taxoquinone could be a remarkable therapeutic candidate for its pharmaceutical applications. 